\title{
Disciplinárna zodpovednost' v Slovenskej republike s osobitným zretel'om na disciplinárne delikty štátnych zamestnancov
}

\section{Disciplinary responsibility in the Slovak Republic with particular regard to the disciplinary offenses of civil servants}

\author{
Róbert Gyuri, Michal Jesenko \\ https://doi.org/10.33542/VSS2019-2-01
}

\begin{abstract}
The article focuses on current issues related to disciplinary responsibility and its position in the legal order of the Slovak Republic. It focuses mainly on the theoretical definition of disciplinary liability, terminological problems, concurrence of disciplinary liability and other torts in the Slovak Republic and the right to judicial protection before the European Court of Human Rights. The second part examines the disciplinary responsibility of civil servants, their sorting and imposing sanctions for committing a disciplinary offense.
\end{abstract}

Keywords: disciplinary responsibility, the right to judicial protection before the European Court of Human Rights, civil servants

Úvod

Rozsah, v akom verejná správa zasahuje do života jednotlivca, je determinovaný kompetenčnou výbavou subjektov verejnej správy, jej inštitucionálnym a organizačným aparátom a v neposlednom rade aj mierou dôvery spravujúcich subjektov v schopnost' a ochotu spravovaných subjektov rešpektovat' pri realizácii svojich spoločenských vzt’ahov právom stanovené pravidlá (Molitoris, 2016, s. 7). Tieto pravidlá musia nevyhnutne dodržiavat' nie len adresáti verejnej správy, ale aj personálny substrát vykonávatel'ov verejnej správy. $\checkmark$ prípade ich nerešpektovania dochádza spravidla k vzniku verejnoprávnej, najmä administratívnoprávnej zodpovednosti.

Správne delikty patria do skupiny verejnoprávnych deliktov, v prípade ktorých zodpovednost' za porušenie (verejného) práva vyvodzuje štát alebo ním určený iný verejnoprávny subjekt (napr. územná samospráva) a to prostredníctvom nato určených orgánov, ale vždy vo verejnom záujme. Protiprávne konania adresátov verejnej správy v oblasti verejnej správy označené ako správne delikty tvoria početnú skupinu činov 
rôznorodého charakteru a neexistuje zákon, ktorý by legislatívne vymedzoval jednotlivé kategórie správnych deliktov jednotne a komplexne.

Vzhl'adom na charakter súčasnej právnej úpravy možno správne delikty vo všeobecnosti delit' na priestupky a iné správne delikty, pričom iné správne delikty netvoria homogénnu skupinu a d’alej sa vnútorne diferencujú. Do skupiny iných správnych deliktov patria aj disciplinárne delikty, vrátane disciplinárnych deliktov osobitnej kategórie štátneho aparátu - štátnych zamestnancov, ktorých analýzou sa budeme zaoberat' v predmetnej štúdii.

\section{Vybrané teoreticko-aplikačné aspekty disciplinárnej zodpovednosti v Slovenskej republike}

Disciplinárna zodpovednost', na rozdiel od iných druhov zodpovednosti, sa uplatňuje voči osobe, ktorá má určitý právny vzt’ah k určitej organizačnej štruktúre určitého subjektu alebo orgánu, ktorý vzniká napríklad na základe pracovnej zmluvy, menovaním alebo vol'bou ako pracovný, služobný, členský alebo iný pomer. Zavinené porušenie disciplíny môže mat' za následok uloženie disciplinárnej sankcie (Machajová, 2007, s. 221). Takáto sankčná zodpovednost' môže vzniknút' len vnútri určitej organizačnej štruktúry určitého subjektu, ktorej je fyzická osoba členom, zamestnancom, príslušníkom, funkcionárom alebo je v obdobnom postavení, pričom nemá a nemá mat' vonkajšie účinky na subjekty stojace mimo danú organizačnú štruktúru. Disciplinárny delikt má teda vnútro-organizačný charakter, a preto sa jeho dôsledky prejavujú len interne vo vzt’ahu k danej organizačnej štruktúre.

Existencia a uplatňovanie disciplinárnej zodpovednosti je výrazom potreby zaistit' dodržiavanie predpísaných pravidiel $v$ relatívne ucelených a $v$ stabilizovaných organizačných sústavách. Ako právna zodpovednost' nie je disciplinárna zodpovednost' inštitútom jediného právneho odvetvia. Preto disciplinárna zodpovednost' ako zodpovednost' správno-právna je určitou čast'ou (resp. výsekom alebo súčast'ou) disciplinárnej zodpovednosti upravenej právom (Průcha, 2003, s. 214).

Vzt’ahy súvisiace $s$ uskutočňovaním disciplinárnej zodpovednosti majú mocenský charakter, vyjadrujú nadriadenost' zamestnávajúceho a podriadenost' zamestnanca právneho vzt’ahu. Pri uplatňovaní disciplinárnej zodpovednosti zodpovednostný vzt’ah vzniká medzi subjektom, ktorý porušil, resp. nesplnil osobitné právne povinnosti vyplývajúce z príslušného právneho vzt’ahu, a tým, kto mu je na základe tohto právneho vzt’ahu nadriadený. Pre súkromnoprávne úpravy, založené na vzt’ahoch rovnosti subjektov, je disciplinárna zodpovednost' neprijatel'ná, vylučuje to samotná povaha veci (Kuril, 2016, s. 39). Ďalším znakom týchto vzt'ahov je, že majú verejnoprávny charakter. Nepostačuje teda, že ide o osobu s právnym vzt’ahom $\mathrm{k}$ nositel'ovi verejnej správy, ak verejnoprávne prvky v tomto vzt'ahu neprevažujú (Košičiarová, 2017, s. 247). Zo systému disciplinárnej zodpovednosti sú tak vylúčení tí zamestnanci orgánov verejnej správy či verejnej moci, ktorí vykonávajú závislú 
prácu $v$ režime bežného pracovného pomeru (spravujúcom sa Zákonníkom práce) alebo v režime výkonu práce vo verejnom záujme (podla zákona č. 552/2003 Z. z. v znení neskorších predpisov).

Vznik disciplinárneho práva je spojený so vznikom špecifického verejnoprávneho (služobného) pomeru medzi štátom a jeho zamestnancami. Na prelome 19. a 20. storočia sa všeobecne prijalo, že disciplinárne právo nie je chápané ako zvláštny osobitný druh trestného práva, ale samostatný subsystém správneho práva (Mates - Mazanec, 1997, s. 593). V priebehu d’alšieho vývoja sa začala právna úprava disciplinárneho práva vnútorne diferencovat'. Podl'a S. Košičiarovej sa v súčasnosti možno stretnút' s disciplinárnymi deliktami páchanými v oblasti výkonu verejnej moci (vrátane štátnej správy), v oblasti verejnej záujmovej samosprávy alebo $v$ iných špecifických vnútorných vzt'ahoch verejnoprávnych inštitúcií (Košičiarová, 2017, s. 247). Disciplinárna zodpovednost' tak už nie je výlučne doménou správneho práva a verejnej správy, ale uplatňuje sa aj v iných verejnoprávnych odvetviach, či vo sfére súkromnoprávnych vztahov Popri správnych disciplinárnych deliktoch (napríklad štátnych zamestnancov, osôb v iných služobných pomeroch a pod.) tak existujú aj d’alšie verejnoprávne disciplinárne delikty, ku ktorých páchaniu dochádza mimo organizácie verejnej správy (napríklad disciplinárne delikty sudcov, prokurátorov, poslancov parlamentu a pod.) ako aj celá skupina súkromnoprávnych disciplinárnych deliktov (napríklad disciplinárne delikty členov družstva, členov občianskeho združenia, členov politickej strany alebo politického hnutia a iné).

\subsection{Problémy terminologického vymedzenia a charakteristika disciplinárnych deliktov}

Ako už bolo vyššie uvedené, jedným z druhov správnych deliktov v Slovenskej republike sú správne disciplinárne delikty. Správne disciplinárne delikty, ktoré patria do kategórie tzv. „správnych deliktov", presnejšie zarad'ujeme do skupiny medzi tzv. „iné správne delikty".

Konkrétna právna úprava, ako tomu často býva v slovenskej legislatíve, však často neprihliada na terminologické označovanie a vymedzenie zaužívané v administratívnoprávne teórii a označuje predmetný delikt inak, dokonca na mnohých miestach nejednotne. Na označenie disciplinárnych deliktov pri disciplinárnej zodpovednosti používajú osobitné právne predpisy i pojmy „disciplinárne previnenie" (napr. § 52 zákona č. 73/1998 Z. z. o štátnej službe príslušníkov Policajného zboru, Slovenskej informačnej služby, Zboru väzenskej a justičnej stráže SR a Železničnej polície v znení neskorších predpisov), „služobné previnenie“ (napr. § 75 zákona č. 315/2001 Z. z. o Hasičskom a záchrannom zbore v znení neskorších predpisov) alebo aj nepresné zákonné pomenovanie typu „disciplinárny priestupok“ (napr. § 72 zákona č. 131/2002 Z. z. o vysokých školách v znení neskorších predpisov). 
Pri pojme „disciplinárny priestupok“ ide o nepresné zákonné označenie pre pojem správny disciplinárny delikt spáchaný študentom vysokej školy. $V$ tomto prípade považujeme predmetné označenie disciplinárneho deliktu za výslovne nešt'astné a nevhodné legislatívne riešenie. $V$ danom prípade sa jeden druh deliktu (disciplinárny delikt) označuje názvom iného druhu deliktu (priestupok) a na odlišenie sa pripojí len adjektívum („disciplinárny“). Predmetné označenie považujeme za mätúce a nerešpektujúce systém a rozdiely medzi jednotlivými druhmi správnych deliktov, $v$ tomto prípade priestupkov a disciplinárnych deliktov. Takéto označenie môže navyše evokovat', že v tomto prípade ide o osobitný druh priestupku, na vyvodzovanie zodpovednosti ktorého sa uplatní priestupkovo-právna úprava, čo v skutočnosti neplatí.

Máme za to, že jednotlivé legislatívne nepresnosti v tejto oblasti môžeme preklenút' aspoň čiastočne - ich dôslednejším teoretickým vymedzením. Podl'a administratívnoprávnej teórie možno disciplinárne delikty charakterizovat' ako porušenie právnej povinnosti $v$ oblasti verejnej správy fyzickou osobou, o ktorom rozhoduje subjekt alebo vykonávatel' verejnej správy splnomocnený na základe zákona disciplinárnou právomocou, pričom disciplinárna zodpovednost' za porušenie služobných alebo členských povinností v organizačnom režime je založená alebo vyvodená na základe zákonného splnomocnenia (Vrabko, 2018, s. 218). Ďalej ho môžeme aj vymedzit' ako delikt fyzickej osoby, ktorá je v osobitných právnych vzt'ahoch $\mathrm{k}$ určitej inštitúcii s osobitnými právami a povinnost’ami vyplývajúcimi práve z tohto služobného, zamestnaneckého, členského, resp. obdobného vzt'ahu. Môže íst' o inštitúcie štátne (napríklad polícia, orgány štátnej správy, ozbrojené sily, ozbrojené zbory), profesijné komory alebo iné inštitúcie (napríklad verejné vysoké školy) (Prášková, 2006, s. 450). Špecifikum tohto druhu deliktu spočiva predovšetkým $v$ tom, že porušená povinnost' súvisí s príslušnost'ou fyzickej osoby k určitej organizácii a že ide o povinnost’ formulovanú v rámci pravidiel, ktoré upravujú fungovanie tejto ustanovizne (Škultéty, 2004, s. 173), pričom pravidlá danej ustanovizne musia mat' právny základ, teda musí íst' o porušenie právnej povinnosti (Mates, 2000, s. 73).

\section{2 Ústavnoprávne princípy vyvodzovania disciplinárnej zodpovednosti. Možnosti súbehu postihu disciplinárnych deliktov a iných verejnoprávnych deliktov}

Rovnako ako v prípade trestnoprávneho či iného verejnoprávneho postihu páchatel'a verejnoprávneho deliktu, aj na vyvodzovanie disciplinárnej zodpovednosti je nevyhnutné aplikovat' ústavné princípy v oblasti trestania (resp. ukladania sankcií). Z požiadaviek ústavného práva jasne vyplýva, že princípy trestania možno odvodit' jednak z ústavných požiadaviek na uplatňovanie verejnej moci, z princípov demokratického a právneho štátu a $v$ neposlednom rade aj z požiadaviek obsiahnutých $v$ medzinárodných zmluvách. Ich účelom je zabezpečit' humánnost' a spravodlivost' trestania. 
Bez ohl'adu na kategorizáciu jednotlivých verejnoprávnych deliktov pri ich prejednávaní a ukladaní sankcií za ne príslušný orgán je povinný rešpektovat' princípy, ktoré vyplývajú z Ústavy Slovenskej republiky, a to bez ohladu na to, či sú v jej texte vyjadrené explicitne alebo je ich možné vyvodit' len implicitne. K princípom, ktoré sa musia uplatňovat' pri vyvodzovaní právnej zodpovednosti nepochybne patrí: princíp nullum crimen sine lege (požiadavka na určité, jasné a presné vyjadrenie skutkových podstát správnych deliktov v zákone), princíp nulla poena sine lege (požiadavka, aby zákon ustanovil uzavretý výpočet sankcií vrátane hladísk pre výber druhu a výmery sankcie), zákaz retroaktivity prísnejšieho zákona (nullum crimen, nulla poena sine lege praevia) - ide o výnimku z časovej pôsobnosti ochrannej správnej normy, ked'že sa zásadne uplatňuje pravidlo, podla ktorého trestnost' správania sa posudzuje a trest sa ukladá podl'a zákona účinného v čase, ked' bol správny delikt spáchaný), princíp zákazu analógie v neprospech páchatel'a správneho deliktu (in mala partem), princíp ne bis in idem (nik nemôže byt' stíhaný a potrestaný za rovnaký skutok viackrát na základe toho istého zákonného ustanovenia), princíp subsidiarity trestného postihu (ultima ratio) - vyvodzovanie zodpovednosti má miesto len tam, kde nepostačujú iné nástroje a prostriedky a princíp humánnosti a rešpektovania ludskej dôstojnosti (Košičiarová, 2019, s. 47-48).

V nasledujúcom texte zameriame našu pozornost' výlučne na princípy ne bis in idem a ultima ratio a sústredíme sa aspoň v základnom rámci na skúmanie možnosti súbehu postihu páchatela súčasne za disciplinárny delikt a iný verejnoprávny delikt.

V právnej teórii i aplikačnej praxi pri otázke vyvodzovania právnej zodpovednosti a následnom trestaní či sankcionovaní páchatel'a deliktu sa uplatňuje zásada ne bis in idem v kombinácii a spolupôsobení so zásadou ultima ratio, čím sa sleduje zabráneniu stavu dvojitého postihu páchatel'a za ten istý skutok. Ich účelom je teda zabránit', aby páchatel' verejnoprávneho deliktu nebol potrestaný viackrát za jedno protiprávne konanie. Rovnako vyjadrujú požiadavku obmedzit' stíhanie osôb a ich trestanie na prípady, ked' je to odôvodnené spoločenskou škodlivost'ou ich protiprávneho správania. Tieto zásady sa uplatňujú v celom systéme verejnoprávnych deliktov. Ide v podstate o situácie, kedy jeden subjekt svojim jedným konaní contra legem naplní skutkovú podstatu deliktu vo viacerých právnych predpisoch, ktoré upravujú rôzne druhy právnej zodpovednosti. Ide o situácie, kedy obsahová náplň skutkových podstát rôznych druhov deliktov je $v$ zásade obdobná a odlišuje sa spravidla len stupňom spoločenskej závažnosti. Ako príklad je možné uviest' trestné činy a priestupky. Súbehu potrestania za oba delikty súčasne v týchto prípadoch bráni „legislatívna brzda“, ktorá je inkorporovaná v samotnej definícii priestupku § 2 ods. 1 in fine zákona č. 372/1990 Zb. o priestupkoch v znení neskorších predpisov (d’alej len zákon o priestupkoch), podla ktorej „Priestupkom je zavinené konanie, ktoré porušuje alebo ohrozuje záujem spoločnosti a je za priestupok výslovne označené $v$ tomto alebo $v$ inom zákone, ak nejde o iný správny delikt 
postihnutel'ný podla osobitných právnych predpisov, alebo o trestný čin“. Z uvedeného vyplýva, že hoci konanie páchatel' naplní ktorúkol'vek skutkovú podstatu priestupku uvedenú v zákone o priestupkoch alebo v osobitnom zákone, ale zároveň naplní znak skutkovej podstaty trestného činu podl'a trestného zákona, pôjde „prioritne“ o trestný čin a nie priestupok. Trestná zodpovednost' a jej vyvodzovanie má v právnom poriadku pred priestupkami prednost' a páchatel takýchto deliktov bude „len“ trestnoprávne zodpovedný a priestupku sa v takomto prípade nedopúšta. Takýmto legislatívno-technickým spôsobom sa zamedzuje dvojitému postihu páchatel'a za trestný čin a zároveň priestupok.

Iná situácia je však nastáva v prípade súbehu trestného činu či priestupku, poprípade iného správneho deliktu, a disciplinárneho deliktu. $\vee$ tomto prípade páchatel' dopúšt’ajúci sa disciplinárneho deliktu porušuje svojim konaním vnútorný „disciplinárny“ poriadok organizácie, ktorej je členom či inak súčast’ou (napríklad služobnú disciplínu štátneho zamestnanca) a dané konanie zároveň napiňa ja skutkovú podstatu niektorého verejnoprávneho deliktu (napríklad trestného činu). Máme za to, že táto situácia je iná a v tomto prípade nedochádza s skutočnostiam, ktoré odôvodňujú zákaz súbehu a teda dvojitý postih páchatel' za ten istý skutok v pravom zmysle slova. $\mathrm{V}$ jednom prípade sa konaním porušuje vnútorný poriadok danej inštitúcie, $v$ druhom prípade ohrozuje alebo porušuje celospoločenský verejný záujem a zákonom chránené hodnoty. A to aj napriek skutočnosti, že k obom deliktom došlo jedným páchatel'ovým konaním. Rozdiel je tu však daný iným objektom týchto deliktov. Kým v prípade disciplinárnych deliktov je objektom napríklad riadny výkon verejnej služby a tým bezporuchový chod danej inštitúcie (t. j. vnútorný poriadok), v prípade iného verejnoprávneho deliktu je jeho objektom spravidla celospoločenský verejný záujem chránený zákonom (tzv. verejný poriadok). Potrestanie páchatel' iba za porušenie jedného z nich by sa podla nášho názoru minulo účinkom a bolo by nepostačujúce. A to aj napriek tomu, že sankcia za „prísnejši“ delikt (napríklad trestný čin) by postihla páchatel' dostatočne invazívnym spôsobom. Navyše nie je možné vylúčit' len $v$ dôsledku súbehu verejnoprávneho deliktu a disciplinárneho deliktu potrebu uloženia sankcie zo strany organizácie, ktorej sa člen dopustil disciplinárneho deliktu porušením jej vnútorného poriadku. Máme za to, že tento argument o. i. do velkej miery odôvodňuje skutočnost', že súbeh disciplinárnej zodpovednosti a iného verejnoprávneho deliktu je možný. Pri trestaní za disciplinárny delikt je teda podla nášho názoru minimálne sporné uplatnenie zásad ne bis in idem a ultima ratio.

Ďalším argumentom podporujúcim tvrdenie o možnom súbehu disciplinárnej zodpovednosti a d’alších verejnoprávnych deliktov je aj na niektorých miestach samotná legislatíva. Príkladom je zákon o priestupkoch, ktorý výslovne počíta s možnost'ou dvojitého potrestania za ten istý skutok. Ako dôkaz možno poukázat' na $\S 12$ ods. 1 zákona o priestupkoch, kde je jasne zakotvené, že pri určení druhu sankcie a jej výmery sa prihliadne tiež na to, či a akým spôsobom bol za ten istý skutok postihnutý v kárnom alebo $v$ 
disciplinárnom konaní. Alebo i na $\S 66$ ods. 2 písm. d) a $\S 76$ ods. 1 písm. ch) zákona o priestupkoch, kde je uvedené, že správny orgán vec d’alej odloží alebo zastaví, ak o skutku sa už rozhodlo $v$ kárnom alebo $v$ disciplinárnom konaní a uložené opatrenie alebo vydané rozhodnutie sa považuje za postačujúce.

Objavujú sa však aj názory, podl'a ktorých ak bola osoba pre ten istý skutok potrestaná ako za trestný čin, a to (z časového hladiska) skôr, ako za disciplinárny delikt, zásada ne bis in idem a ultima ratio platí a takúto osobu nemožno už potrestat' za disciplinárny delikt, ak ide o ten istý skutok (napríklad: Machajová, 2009, s. 224). Podla S. Košičiarovej v prípade súbehu deliktov s rôznym stupňom spoločenskej škodlivosti ${ }^{1}$ (napr. disciplinárne previnenie priestupok), má z hmotnoprávneho hl'adiska prednost' stíhanie deliktu s vyšším stupňom spoločenskej škodlivosti. Ak sa preto už o skutku právoplatne rozhodlo ako o delikte s vyšším stupňom spoločenskej škodlivosti, neprejedná sa, pokial' sa toto rozhodnutie považuje za postačujúce. Ak zákon nevylučuje (na základe zásady špeciality) súbeh disciplinárneho previnenia s trestným činom alebo s niektorou z kategórií správnych deliktov, prednost' bude mat' postih trestného činu a správneho deliktu pred postihom disciplinárneho previnenia. Či je súbeh vylúčený, treba skúmat' od zákona k zákonu, žiadna legislatívna jednota tu neexistuje (Košičiarová, 2019, s. 52).

$S$ týmto názorom $v$ zásade súhlasíme, avšak máme za to, že $v$ niektorých prípadoch disciplinárnej zodpovednosti (ako príklad je možné uviest' disciplinárnu zodpovednost' študentov vysokých škôl) môže dôjst' k vyvodeniu ich disciplinárnej zodpovednosti aj ex post po vyvodení ich trestnoprávnej zodpovednosti za ten istý skutok. Otázku možného súbehu verejnoprávneho deliktu a následného vyvodzovania disciplinárnej zodpovednosti však považujeme za stále otvorenú a jednoznačne nevyriešenú. Máme za to, že otázka možného súbehu pri vyvodzovaní verejnoprávnej zodpovednosti (disciplinárneho deliktu a iného verejnoprávneho deliktu) by mala byt' riešená legislatívnym spôsobom expressis verbis, čím by sa zamedzilo aplikačným problémom a nevyjasneným otázkam $v$ tejto oblasti zodpovednostných právnych vzt’ahov.

\subsection{Disciplinárna zodpovednost' a právo na súdnu ochranu pred ESL’P}

$\mathrm{Na}$ tomto mieste je dôležité uviest', že pri vyvodzovaní právnej zodpovednosti za disciplinárne delikty je v zásade vylúčené právo na súdnu ochranu pred Európskym súdom pre ludské práva (d’alej len ESL'P) v zmysle článku 6 Dohovoru o ochrane luudských práv a základných slobôd (d’alej len Európsky dohovor). Na druhej strane je pravdou, že na čast'

\footnotetext{
1 Podla S. Košičiarovej sa stupňom spoločenskej škodlivosti deliktu rozumie stupeň typovej spoločenskej škodlivosti. Ten je určený zákonom. V slovenskej právnej úprave sa uplatňuje pravidlo, že najvyšší stupeň typovej spoločenskej škodlivosti majú trestné činy. $V$ hierarchickom rebričku nasledujú správne delikty a najnižší stupeň typovej spoločenskej škodlivosti vykazujú disciplinárne delikty.
} 
správnych disciplinárnych deliktov sa vzt’ahuje aplikácia, ochrana a dodržiavanie práva na súdnu ochranu, a tým aj jurisdikcia ESL'P. Je to hlavne pri správnych disciplinárnych deliktoch členov organizácií záujmovej, resp. profesijnej a stavovskej samosprávy v prípadoch, v ktorých bol na ne prenesený výkon štátnej správy $v$ určitej oblasti (napríklad rozhodnutia ESL'P vo veciach Diennet v. Francúzsko (z 26. septembra 1995, Annuaire, č. 235-A) alebo W. R. v. Rakúsko (z 21. decembra 1999)). Pri správnych disciplinárnych deliktoch osôb v štátnej službe, v služobnom alebo v obdobnom pomere, ako aj pri správnych disciplinárnych deliktoch osôb pozbavených osobnej slobody na základe rozhodnutia súdu je z pohl'adu aplikácie článku 6 Európskeho dohovoru dôležitá predovšetkým závažnost' im uloženej sankcie za spáchaný disciplinárny delikt, pričom ide najmä o profesionálnych vojakov, príslušníkov ozbrojených síl a o odsúdených (Svák, 2011, s. 137-159). Správne disciplinárne delikty s miernejšími sankciami sú spolu s disciplinárnymi sankciami štátnych zamestnancov postavené mimo záruky článku 6 Európskeho dohovoru (Machajová, 2007, s. 224).

$\mathrm{Na}$ druhej strane je nevyhnutné poznamenat', že represívnu funkciu vyvodzovania zodpovednosti aj za disciplinárne delikty judikatúra ESL'P nepoprela. V rozsudku Engel c. Holandsko (z 8 . júna 1976) súd síce pripustil špecifickost' disciplinárnych deliktov, ale súčasne zdôraznil, že tá sama nevylučuje povinnost' prihliadat' na podstatu skutku a jeho postihu. To, že ESL'P označuje spory vzniknuté vo veciach disciplinárnej zodpovednosti za spory o občianskoprávnom záväzku, neznamená, že v podmienkach Slovenskej republiky by sa mali považovat' za súkromnoprávne spory, $v$ ktorých je daná právomoc súdu $v$ civilnom procese (Košičiarová, 2019, s. 47). Uvedenú skutočnost' podporuje aj platná právna úprava na Slovensku, ked' zarad'uje disciplinárne delikty medzi správne delikty (§ 71 ods. 1 zákona č. 162/2015 Z. z. Správny súdny poriadok v znení neskorších predpisov) a ked' zveruje právomoc preskúmat' rozhodnutia disciplinárnych orgánov správnemu súdnictvu (§ 194 ods. 1 Správneho súdneho poriadku).

\section{Disciplinárna zodpovednost' zamestnancov v štátnej službe}

Právna úprava postavenia štátnych zamestnancov sa považuje za dôležitú oblast' spoločenských vzt'ahov. Štátni zamestnanci sa v podstatnej miere priamo zúčastňujú na tvorbe a realizácii nielen výkonu štátnej správy, ale aj štátnej politiky ako takej. Je nevyhnutné, aby právna úprava štátnozamestnaneckých vzt’ahov predstavovala jednotný, stabilný a funkčný systém, ktorý zabezpečuje štátnym zamestnancom nevyhnutné podmienky na riadne vykonávanie štátnej služby a vytvára priestor na odborné plnenie úloh orgánov štátnej správy a úloh štátnych orgánov vykonávajúcich štátne záležitosti (Križan - Žofčinová, 2013, s. 179). Existencia a uplatňovanie vnútorných zodpovednostných právnych vzt'ahov je nevyhnutnou súčastou existencie a možného efektívneho fungovania uvedeného mechanizmu. 
Disciplinárna zodpovednost' je jedným z najtypickejších znakov verejnoprávnej povahy zamestnaneckých vzt'ahov v štátnej službe, v ktorých sa prejavuje mocenský, nerovný pomer jedného zo subjektov týchto vzt'ahov smerom $\mathrm{k}$ druhému. Disciplinárna zodpovednost' predstavuje jeden z imanentných znakov zamestnaneckých vzt’ahov v štátnej službe, vyplýva zo samotnej podstaty týchto vzt'ahov, bezprostredne sa dotýka vnútornej stránky týchto vzt'ahov. Disciplinárna zodpovednost' vystupuje v zamestnaneckých vzt'ahoch pri výkone štátnej služby do popredia ešte výraznejšie, ako je to $v$ pracovnoprávnych vzt'ahoch vznikajúcich na trhu práce. Vyplýva to z poslania zamestnaneckých vzt’ahov v štátnej službe, z osobitostí plnenia úloh v štátnej službe, zo vzt’ahov nadriadenosti a podriadenosti v štátnej službe. Význam inštitútu disciplinárnej zodpovednosti súvisí tiež s dodržiavaním služobnej disciplíny, v zmysle súhrnu služobných povinností vyplývajúcich pre štátneho zamestnanca z príslušného zákona o štátnej službe, ked'že porušenie služobnej disciplíny (služobných povinností) môže zakladat' uplatnenie disciplinárnej zodpovednosti, (ale za určitých okolností aj hmotnú či trestnú zodpovednost'). Ustanovenia o disciplinárnej zodpovednosti sú integrálnou súčastou príslušnej právnej úpravy jednotlivých skupín štátnych zamestnancov (Kuril, 2016, s. 39).

Disciplinárna zodpovednost', ako sme už vyššie uviedli, je jedným z typických a charakteristických znakov zamestnaneckých vzt’ahov v štátnej službe. Administratívnoprávnej povahe disciplinárnej zodpovednosti zodpovedá aj povaha chránených vzt'ahov, v ktorých štátny zamestnanec plní nielen povinnosti súvisiace s pracovnou činnostou, ale aj osobitné povinnosti vyplývajúce predovšetkým z noriem správneho práva, ked' vykonáva činnost' menom štátu a plní úlohy a funkcie štátu. Disciplinárna povinnost' v štátnej službe vyplýva zo zákona, je sankciou za porušenie zákona. Skutkovým základom disciplinárnej zodpovednosti štátnych zamestnancov je disciplinárny delikt (disciplinárne previnenie), t. j. protiprávne konanie narušujúce služobnú disciplínu, vymedzenú právnymi predpismi, ale aj vnútornými pokynmi. Pre určenie podstaty disciplinárnej zodpovednosti je tiež charakteristická povaha povinností, ktorých porušenie je disciplinárnym deliktom. Vzhladom na to, že v štátnej službe sa uplatňuje zvýšená miera povinností subjektov týchto vztahov, v porovnaní so všeobecnou mierou povinností ostatných občanov, možno z tohto pohl'adu konštatovat', že aj disciplinárna zodpovednost' je zodpovednost'ou zvýšenou, uplatňujúcou sa ako dôsledok porušenia zvláštnych právnych povinností, vyplývajúcich z vnútroorganizačného vzt'ahu subjektu k určitej organizácii (Červený,1990, s. 44). Pre uplatňovanie disciplinárnej zodpovednosti v štátnej službe je príznačné, že subjekt, ktorý porušil služobnú disciplínu, je vo vzt’ahu podriadenosti voči tomu, kto disciplinárnu zodpovednost' uplatňuje, a to dovtedy, kým subordinačný vzt'ah trvá. Subjekt oprávnený realizovat' disciplinárnu zodpovednost' má zo zákona zverenú disciplinárnu právomoc. Disciplinárna právomoc je právnym nástrojom uplatňovania disciplinárnej zodpovednosti, spravidla býva zverená bud' hierarchicky nadriadenému orgánu 
( $v$ tomto prípade je výhodou dobrá a bezprostredná znalost' pomerov, pružnost' v rozhodovaní), alebo nezávislému kolektívnemu orgánu, najčastejšie disciplinárnym komisiám ( $v$ tomto prípade sa výhodou zdá väčšia objektivita, menšie riziko subjektivizmu). V súvislosti $\mathrm{s}$ uplatňovaním disciplinárnej právomoci sa prikláňame $\mathrm{k}$ tým názorom $\mathrm{v}$ našej teórii i praxi, $\mathrm{v}$ zmysle ktorých chápeme disciplinárnu právomoc ako čast' štátnej moci. $\mathrm{V}$ tomto zmysle disciplinárnu právomoc chápeme ako súčast' výkonu štátnej moci, orgány realizujúce disciplinárnu právomoc majú postavenie orgánov štátnej moci, pri uplatňovaní disciplinárnej právomoci konajú vo svojom mene, nie v mene zamestnávatela, disciplinárna právomoc je im zverená ad personam (Kuril, 2016, s. 40).

Vlastná disciplinárna zodpovednost' zamestnancov v štátnej službe, na ktorú chceme v predmetnej štúdii d’alej upriamit' pozornost', patrí do systému disciplinárnej zodpovednosti vo verejnej správe, a to popri vyvodzovaní zodpovednosti za správne disciplinárne delikty osôb v služobnom alebo $v$ obdobnom pomere (napríklad policajtov, colníkov a pod.), správne disciplinárne delikty členov organizácií záujmovej, resp. profesijnej a stavovskej samosprávy, správne disciplinárne delikty žiakov a študentov škôl ako aj správne disciplinárne delikty osôb pozbavených osobnej slobody na základe rozhodnutia súdu. $\mathrm{Na}$ tomto mieste chceme upriamit' našu pozornost' výlučne na otázku disciplinárnej zodpovednosti osôb v štátnej službe, ktorými sú podla $§ 7$ ods. 1 zákona č. 55/2017 Z. z. o štátnej službe v znení neskorších predpisov (d’alej len zákon o štátnej službe) občania, ktorí vykonávajú štátnu službu v štátnozamestnaneckom pomere v služobnom úrade $v$ príslušnom odbore štátnej služby alebo bez určenia odboru štátnej služby a ktorí sa dopustili disciplinárneho deliktu, ako aj na špecifiká, ktorými sa disciplinárna zodpovednost' tejto kategórie zamestnancov odlišuje od ostatných prípadov.

\subsection{Disciplinárne delikty štátnych zamestnancov $v$ recentnej právnej úprave}

Disciplinárna zodpovednost' osôb v štátnej službe je v súčasnosti čiastočne upravená v príslušných ustanoveniach zákona o štátnej službe. Na tomto mieste sa čiastočne prikláňame k názoru S. Košičiarovej, podla ktorej právna úprava na Slovensku neupravuje tzv. úradnícke disciplinárne delikty, ktorými sa - podla teórie správneho práva - rozumejú disciplinárne delikty štátnych zamestnancov vykonávajúcich štátnu službu $v$ štátnozamestnaneckom pomere. Podla zákona o štátnej službe štátny zamestnanec síce zodpovedá za porušenie služobnej disciplíny (pozri § 117 zákona o štátnej službe), avšak jej porušenie môže byt' len dôvodom pre to, aby služobný úrad okamžite skončil štátnozamestnanecký pomer štátneho zamestnanca (pozri nižšie; pozn. aut.). V zákone nie je upravená právomoc služobného úradu (expressis verbis, pozn. aut.) rozhodovat' o disciplinárnych opatreniach, t. j. o sankciách (Košičiarová, 2017, s. 247). 
Disciplinárna zodpovednost' štátneho zamestnanca (vykonávajúceho štátnu službu v štátnozamestnaneckom pomere) za porušenie služobnej disciplíny sa spravuje $§ 117$ - 121 zákona o štátnej službe. Zákon o štátnej službe na tomto mieste ustanovuje, čo sa považuje za porušenie služobnej disciplíny štátnym zamestnancom, ako sa posudzuje závažnost' porušenia služobnej disciplíny, aké porušenia služobnej disciplíny sa rozoznávajú podla miery ich závažnosti a aký následok má podl'a zákona menej závažné porušenie služobnej disciplíny, opakované menej závažné porušenie služobnej disciplíny a závažné porušenie služobnej disciplíny.

Podla § 117 zákona o štátnej službe „Štátny zamestnanec zodpovedá za porušenie služobnej disciplíny, ktorou je nesplnenie alebo porušenie povinností alebo obmedzeni vyplývajúcich z tohto zákona, ktoré sa vzt’ahujú na vykonávanie štátnej služby, ak $k$ ich nesplneniu alebo porušeniu došlo v súvislosti s výkonom štátnej služby“. Takýmto konaním sa štátny zamestnanec dopúšt'a disciplinárneho deliktu.

\subsection{Niekol'ko poznámok k znakom skutkovej podstaty disciplinárnych deliktov štátnych zamestnancov}

Správne disciplinárne delikty štátnych zamestnancov sa odlišujú od ostatných verejnoprávnych deliktov najmä $\vee$ tom, že ich subjekt je vždy špeciálny, nemôže ním byt' hocikto, ale iba osoba prislúchajúca k danej ustanovizni (Prášková, 2006, s. 450), t. j. štátny zamestnanec podla $\S 7$ ods. 1 zákona o štátnej službe. $\vee$ tomto prípade ide o fyzickú osobu, ktorá je v osobitnom štátnozamestnaneckom vzt'ahu $k$ určitému orgánu štátnej správy $-\mathrm{t}$. j. v služobnom úrade, a to s osobitnými právami a povinnost’ami vyplývajúcimi práve $z$ tohto vzt’ahu. Objektom disciplinárneho deliktu štátneho zamestnanca je riadny výkon štátnej služby a s tým súvisiaca služobná disciplína (u štátnych zamestnancov je to štátna disciplína), t. j. disciplína a poriadok vnútri organizácie štátnej správy. Popri vnútornom poriadku môže byt’ podla $\mathrm{H}$. Práškovej ich objektom i profesijná etika, odbornost' výkonu povolania, dôstojnost' a dôveryhodnost' inštitúcie voči verejnosti (Prášková, 2006, s. 450). Máme však za to, že objektom disciplinárnych deliktov je $v$ širšom ponímaní aj celkovo bezporuchový chod príslušnej štátnej inštitúcie a jej činnosti, ktorou je výkon štátnej správy. Objektívnou stránkou ako znakom skutkovej podstaty disciplinárneho deliktu štátnych zamestnancov je konanie $v$ podobe aktívneho konania (tzv. facere), nekonania (tzv. nonfacere) alebo opomenutia konania (tzv. omittere), ktoré spočíva v porušení právnych povinností súvisiacich s výkonom štátnej služby (Škultéty, 2002, s. 157). Porušenie právnych povinností však predpokladá, že povinnosti mali právnu podobu, t. j. boli stanovené právnou normou. Subjektívna stránka týchto deliktov je založená vždy na zavinení, pričom postačuje i zavinenie z nedbanlivosti. 


\subsection{Kategorizácia disciplinárnych deliktov štátnych zamestnancov}

Pri samotných disciplinárnych deliktoch rozoznávame dve skupiny deliktov, pričom kritériom ich rozlišovania je miera závažnosti porušenia služobnej disciplíny. Iné kritérium ich triedenia súčasná právna úprava nepozná a ani sa v zásade neuplatňuje.

Podla miery závažnosti porušenia služobnej disciplíny sa rozlišuje:

a) menej závažné porušenie služobnej disciplíny,

b) závažné porušenie služobnej disciplíny.

Zákon v niektorých prípadoch ustanovuje, ktoré nesplnenie alebo porušenie povinnosti má služobný úrad považovat' za porušenie služobnej disciplíny, avšak posúdenie miery závažnosti daného porušenia ponechal na služobnom úrade. Vzhladom na špecifiká jednotlivých služobných úradov nie je možné, ani vhodné v zákone určovat’ taxatívny výpočet menej závažných porušení služobnej disciplíny a závažných porušení služobnej disciplíny záväzný pre všetky služobné úrady. Zákon však zavádza povinnost' služobného úradu ustanovit' vo svojom služobnom poriadku, aké porušenie alebo nesplnenie povinnosti štátnym zamestnancom bude považovat' za závažné porušenie služobnej disciplíny a stanovuje isté kritériá posúdenia miery závažnosti porušenia služobnej disciplíny. ${ }^{2}$

V prípade menej závažného porušenia služobnej disciplíny môže služobný úrad vydat' upozornenie o porušení služobnej disciplíny, ktoré má slúžit' najmä ako preventívny prostriedok do budúcna, ak síce došlo $k$ porušeniu služobnej disciplíny štátnym zamestnancom, avšak miera jeho závažnosti bola nízka a je predpoklad, že samotné vydanie tohto upozornenia bude mat' u neho dostatočný účinok, aby konaniu, ktorým by mohlo dôjst' k porušeniu služobnej disciplíny $v$ budúcnosti predchádzal. Služobný úrad môže vydat' toto upozornenie len v lehote jedného roka odo dňa, ked' dôvod na jeho vydanie vznikol, inak dané právo zaniká.

V prípade menej závažného porušenia služobnej disciplíny zákon osobitne počíta aj s možnost'ou jeho opakovania. Preto upravuje a zavádza pojem "opakované menej závažné porušenie služobnej disciplíny". Pôjde o prípad, ked' štátny zamestnanec po oznámení upozornenia o menej závažnom porušení služobnej disciplíny najmenej jedenkrát v priebehu šiestich mesiacov poruší služobnú disciplínu v menej závažnej miere. Domnievame sa, že aby služobný úrad mohol konštatovat', že došlo k opakovanému menej závažnému porušeniu služobnej disciplíny je rozhodujúce, či štátny zamestnanec v posledných šiestich mesiacoch po vydaní prvého upozornenia o menej závažnom porušení služobnej disciplíny znova porušil

\footnotetext{
2 Podla $\S 117$ ods. 3 zákona o štátnej službe sa miera závažnosti porušenia služobnej disciplíny posudzuje vzhliadom na povahu porušenej alebo nesplnenej služobnej povinnosti alebo obmedzenia, okolností, za akých k nemu došlo, najmä spôsob a intenzitu konania alebo opomenutia, mieru zavinenia, opakované porušenie služobnej disciplíny, doterajší prístup štátneho zamestnanca k plneniu povinností a dodržiavaniu obmedzení alebo na inú okolnost' a rozsah škody a následok porušenia služobnej disciplíny.
} 
služobnú disciplínu v menej závažnej miere, t. j. nevyžaduje sa, aby v tejto lehote už došlo aj k vydaniu a oznámeniu upozornenia za opakované menej závažné porušenie služobnej disciplíny. Táto otázka spôsobuje $v$ aplikačnej praxi nemalé problémy.

\subsection{Právne následky spáchania disciplinárneho deliktu štátneho zamestnanca}

Ak zameriame našu pozornost' na otázky postihu páchatel'a za rôzne disciplinárne delikty v právnom poriadku SR vo všeobecnosti, môžeme konštatovat', že právna úprava reguluje vhodne niekol'ko druhov sankcií za spáchanie disciplinárneho deliktu, a to s rôznym stupňom intenzity postihu. Ich spoločným znakom je skutočnost', že tieto sankcie predstavujú, u subjektov, voči ktorým smerujú, jednak morálnu, ale aj hmotnú ujmu, nesmerujú bezprostredne k obnoveniu zákonného stavu, ich uplatňovanie smeruje predovšetkým k dosahovaniu preventívno-výchovných účinkov. Ciel'om ukladania disciplinárnych opatrení je prednostne individuálna a všeobecná prevencia, ukladanie disciplinárnych opatrení nesleduje vytvorenie alebo obnovenie pôvodného právneho stavu (Kuril, 2009, s. 178). Vo všeobecnosti sankciami ukladanými za disciplinárny delikt môžu byt' rôzne sankcie peňažného alebo nepeňažného charakteru. Konkrétne to teda môžu byt' sankcie morálneho charakteru (napr. napomenutie), peňažné sankcie (napr. zníženie platu alebo pokuta), sankcie spočívajúce $v$ znížení hodnosti na určitú dobu, sankcie zákazu činnosti a prepadnutia veci, sankcia odvolania zo služobného miesta predstaveného, sankcie znamenajúce zánik služobného alebo členského pomeru (napr. prepustenie zo služobného pomeru alebo vyčiarknutie zo zoznamu príslušnej profesijnej komory) alebo dokonca sankcie spojené so zásahom do osobnej slobody (napr. sankcia väzenia $\vee$ prípade osôb pozbavených osobnej slobody $v$ zariadeniach na výkon väzby alebo trestu odňatia slobody). Pre každý druh disciplinárnych deliktov je upravený v príslušnom predpise vlastný zoznam možných sankcií a jednotná právna úprava či jednotný zoznam sankcií za disciplinárne delikty neexistuje.

Súčasný zákon o štátnej službe však žiadnu z uvedených sankcií neupravuje a sústred'uje sa $v$ rámci postihu za disciplinárny delikt štátneho zamestnanca len na skončenie štátnozamestnaneckého pomeru výpoved’ou (spáchanie disciplinárneho deliktu je jedným zo zákonných dôvodov na výpoved' zo štátnozamestnaneckého pomeru danú zo strany služobného úradu) alebo na okamžité skončenie štátnozamestnaneckého pomeru. Ako sme už uviedli vyššie, podla zákona o štátnej službe štátny zamestnanec síce zodpovedá podla § 117 zákona o štátnej službe za porušenie služobnej disciplíny, avšak jej porušenie môže byt' len dôvodom pre to, aby služobný úrad okamžite skončil štátnozamestnanecký pomer štátneho zamestnanca alebo skončil štátnozamestnanecký pomer štátneho zamestnanca výpoved’ou. $V$ zákone nie je výslovne upravená právomoc služobného úradu rozhodovat' o disciplinárnych opatreniach v podobe iných právnych následkov či sankcií. 
Služobný úrad môže so štátnym zamestnancom z dôvodu opakovaného menej závažného porušenia služobnej disciplíny skončit' štátnozamestnanecký pomer výpoved’ou, avšak len do dvoch mesiacov od oznámenia upozornenia o opakovanom menej závažnom porušení služobnej disciplíny štátnemu zamestnancovi (subjektívna lehota) a najneskôr do jedného roka, odo dňa ked’ dôvod tejto výpovede vznikol (objektívna lehota). V prípade závažného porušenia služobnej disciplíny počíta zákon s možnost'ou okamžitého skončenia štátnozamestnaneckého pomeru alebo s možnost'ou skončenia štátnozamestnaneckého pomeru výpoved'ou. Dôvodová správa k zákonu o štátnej službe pri výklade týchto ustanovení zákona síce uvádza, že „ak sa štátny zamestnanec dopustí závažného porušenia služobnej disciplíny, je s ním služobný úrad povinný bud' okamžite skončit' štátnozamestnanecký pomer alebo skončit' jeho štátnozamestnanecký pomer výpoved’ou“ (Dôvodová správa k zákonu o štátnej službe). Samotný text zákona však hovorí len o možnosti a nie nevyhnutnosti či povinnosti skončenia štátnozamestnaneckého pomeru uvedenými spôsobmi. Skončenie služobného pomeru má teda v týchto prípadoch len fakultatívny a nie obligatórny charakter. Je vecou služobného úradu či voči štátnemu zamestnancovi - páchatel'ovi disciplinárneho deliktu uplatní aj danú, najprísnejšiu alternatívu postihu v podobe skončenia služobného pomeru.

\subsection{Organizačné a procesnoprávne aspekty vyvodzovania zodpovednosti za disciplinárny delikt štátneho zamestnanca}

Subjekt, ktorý je oprávnený a kompetentný posudzovat' spáchanie disciplinárneho deliktu štátneho zamestnanca je generálny tajomník služobného úradu a podporne ním zriadená poradná komisia. Samotné porušenie služobnej disciplíny posudzuje generálny tajomník služobného úradu, a to bud' $z$ vlastného podnetu alebo na návrh vedúceho zamestnanca, do ktorého riadiacej pôsobnosti patrí štátny zamestnanec, ktorého porušenie služobnej disciplíny má byt' posudzované. Vedúci zamestnanec, ktorého podriadený štátny zamestnanec sa mal dopustit' porušenia služobnej disciplíny, môže podat' písomný návrh generálnemu tajomníkovi v lehote 15 dní, odo dňa kedy sa o porušení služobnej disciplíny dozvedel.

Generálny tajomník zriad'uje na účely preskúmania návrhu poradnú komisiu zloženú najmenej z troch členov, pričom počet členov musí byt' nepárny. Členov poradnej komisie a jej predsedu vymenúva generálny tajomník zo štátnych zamestnancov služobného úradu, v ktorom sa poradná komisia zriad'uje. Účelom komisie je preskúmat', či s ohl'adom na všetky okolnosti prípadu štátny zamestnanec porušil služobnú disciplínu a ak áno, v akej miere závažnosti. Zákon d’alej vymedzuje aj okruh osôb, ktoré môžu byt' členom poradnej komisie. Jeden člen poradnej komisie má byt' podla zákona $z$ toho odboru štátnej služby ako štátny zamestnanec, o ktorého porušenie služobnej disciplíny ide, a jeden člen poradnej komisie má 
mat' vysokoškolské vzdelanie druhého stupňa v odbore právo. Členom poradnej komisie má byt' aj zástupca zamestnancov, ktorého určí príslušný odborový orgán.

Predmetné ustanovenie zákona však považujeme z hl'adiska aplikačnej praxe za nešt’astné. Je nesporné, že niektoré služobné úrady nedisponujú štátnym zamestnancom, ktorý by bol z toho istého odboru štátnej služby ako štátny zamestnanec, o ktorého porušenie služobnej disciplíny ide alebo štátnym zamestnancom, ktorý by mal vysokoškolské vzdelanie druhého stupňa $v$ odbore právo. Zákon preto síce zavádza povinnost' pre generálneho tajomníka zriadit' poradnú komisiu v takomto zložení, ak to však z objektívnych príčin na strane služobného úradu nebude možné, samotná dôvodová správa k zákonu o štátnej službe uvádza, že generálny tajomník môže zriadit' komisiu i bez splnenia tejto podmienky. Takéto legislatívne riešenie nemôžeme považovat' za vhodné. Preto je potrebné v rámci úvah de lege ferenda zamysliet' sa nad tým, či nie je potrebné túto liberačnú podmienku (t. j. objektívnu nemožnost' služobného úradu zriadit' komisiu v predpísanom zložení) zakomponovat' priamo do samotného legislatívneho textu a neponechávat' ju len v dôvodovej správe, ktorá je tak v jasnom rozpore so samotným znením zákona.

Ak sa generálny tajomník domnieva, že štátny zamestnanec porušil služobnú disciplínu, písomne oznámi túto skutočnost' poradnej komisii v lehote 15 dní odo dňa, ked' sa o porušení služobnej disciplíny týmto štátnym zamestnancom dozvedel. Táto lehota je zákonná a má prekluzívny charakter. Po jej uplynutí generálny tajomník nemôže vyvodzovat' zodpovednost' voči štátnemu zamestnancovi za porušenie služobnej disciplíny.

Poradná komisia následne vyzve štátneho zamestnanca, o ktorého porušenie služobnej disciplíny ide, a to do desiatich dní od doručenia oznámenia generálneho tajomníka, aby sa $\mathrm{k}$ veci písomne vyjadril v lehote najmenej desiatich dní, pričom musí pripojit' k vyjadreniu dôkazy preukazujúce jeho tvrdenia (okrem tých, ktoré nemôže pripojit' bez svojej viny). Štátny zamestnanec má vždy právo vyjadrit' sa písomne k veci a doložit' poradnej komisii dôkazy ktorými sám disponuje, a ktoré by preukazovali jeho tvrdenia. $\vee$ prípade, že niektoré dôkazy nevie objektívne predložit', je vhodné ich aspoň uviest'.

Poradná komisia je následne povinná zistit' presne a úplne skutočný stav veci a preskúmat' všetky okolností porušenia služobnej disciplíny. Na tento účel si musí zabezpečit' všetky potrebné podklady. Podkladom môže byt' všetko, čo prispeje k zisteniu a objasneniu skutočného stavu veci a je $v$ súlade $s$ právnymi predpismi, najmä vyjadrenie štátneho zamestnanca, iných fyzických osôb, príp. služobných úradov. Služobné úrady sú povinné na žiadost' poradnej komisie oznámit' tie skutočnosti, ktoré majú význam na posúdenie, či došlo k porušeniu služobnej disciplíny. Rozsah a spôsob zistovania podkladov na posúdenie veci určuje poradná komisia. 
Poradná komisia následne vyhotoví písomný záznam o postupe a priebehu preskúmania porušenia služobnej disciplíny a následne ho doručí generálnemu tajomníkovi spolu s odporúčacím písomným stanoviskom, v ktorom uvedie, či došlo k porušeniu služobnej disciplíny a $v$ akej miere závažnosti, a to $v$ lehote 30 dní odo dňa doručenia vyjadrenia $\mathrm{k}$ veci štátnym zamestnancom alebo odo dňa márneho uplynutia lehoty na vyjadrenie štátneho zamestnanca k prejednávanej veci. Stanovisko poradnej komisie má však len odporúčajúci charakter a generálny tajomník nie je pri rozhodovaní stanoviskom komisie viazaný. Generálny tajomník je povinný v lehote 10 dní odo dňa predloženia stanoviska poradnou komisiou, vydat' bud' písomné upozornenie o porušení služobnej disciplíny alebo písomné upovedomenie o tom, že nedošlo k porušeniu služobnej disciplíny, a to $v$ závislosti od toho, $k$ akému záveru dospeje.

Ak generálny tajomník dospeje na základe stanoviska poradnej komisie k záveru, že došlo k porušeniu služobnej disciplíny, vydá upozornenie a to v lehote desiatich dní (odo dňa predloženia stanoviska poradnou komisiou). Generálny tajomník musí v upozornení riadne, jasne a zrozumitel'ne odôvodnit', prečo a na základe čoho dospel k záveru, že štátny zamestnanec porušil služobnú disciplínu. $\mathrm{Na}$ tomto mieste považujeme za dôležité pripomenút', že ak generálny tajomník dospel k záveru, že porušenie alebo nesplnenie povinnosti alebo obmedzenia štátnym zamestnancom malo takú vysokú mieru závažnosti, že došlo k závažnému porušeniu služobnej disciplíny, je obzvlášt' dôležité, aby v upozornení riadne a presvedčivo odôvodnil, akými úvahami sa riadil pri posúdení porušenia služobnej disciplíny, a to s ohl'adom na závažnost's tým spojeného následku (výpoved' alebo okamžité skončenie štátnozamestnaneckého pomeru). Ak generálny tajomník na základe stanoviska poradnej komisie dospeje $\mathrm{k}$ záveru, že nedošlo k porušeniu služobnej disciplíny štátnym zamestnancom, upovedomí ho o tom písomne najneskôr v lehote desiatich dní odo dňa predloženia stanoviska poradnou komisiou.

\section{Záver}

Disciplinárna zodpovednost' ako osobitný druh právnej zodpovednosti je jedným z výrazných, typických a charakteristických znakov zamestnaneckých vzt’ahov v štátnej službe dotvárajúci ich verejnoprávnu povahu. Uplatňovanie disciplinárnej zodpovednosti je jedným z výrazných právnych prostriedkov spojených s dôslednou realizáciou práv a povinností subjektov týchto vzt'ahov. Disciplinárna zodpovednost' v zamestnaneckých vzt'ahoch v štátnej službe má zásadne vnútroorganizačnú povahu, je uplatňovaná vo vnútri týchto vzt’ahov a podliehajú jej iba osoby, ktoré sú $k$ tejto organizácii $v$ určitom organizačnom vzt'ahu. Je výrazom vzt'ahov nadriadenosti a podriadenosti, zánikom štátnozamestnaneckého vzt’ahu končí aj jej uplatňovanie (Kuril, 2016, s. 40). 
Disciplinárna zodpovednost', ako jedna z foriem zodpovednostných právnych vzt'ahov, hoci nie je výlučne doménou správneho práva a verejnej správy, jej uplatňovanie nachádza svoje vyjadrenie najmä vo sfére štátnej správy ako integrálnej súčasti verejnej správy na Slovensku. Konkrétna právna úprava disciplinárnej zodpovednosti, ako tomu často býva $v$ slovenskej legislatíve, často neprihliada na terminologické označovanie a vymedzenie zaužívané $v$ administratívnoprávne teórii a označuje disciplinárne delikty inak, dokonca na mnohých miestach nejednotne. Tento nedostatok sa v rámci akademického výkladu príslušnej legislatívy pokúša preklenút' administratívnoprávna teória, a to jasným definovaním a charakteristikou disciplinárnej zodpovednosti. Aplikačné problémy však neprináša len nejednotné definovanie a označovanie správnych disciplinárnych deliktov, ale najmä otázka možného súbehu jednotlivých verejnoprávnych deliktov. $V$ tejto oblasti nepanuje medzi jednotlivými teoretikmi či odborníkmi jednotný názor. Na základe vyššie predložených argumentov, ktoré sme s pokúsili uviest', je možné konštatovat', že na rozdiel od súbehu iných verejnoprávnych deliktov navzájom je prípad súbehu disciplinárneho deliktu štátneho zamestnanca a iného verejnoprávneho deliktu spáchaného štátnym zamestnancom možný a dokonca miestami až potrebný. V oblasti následného postihu páchatela - štátneho zamestnanca však súčasne platný zákon o štátnej službe nedáva služobnému úradu ako orgánu vyvodzujúceho disciplinárnu zodpovednost' širokú škálu možných sankcií za porušenie služobnej disciplíny, ktoré by mohli prihliadat' na rôzne aspekty v naplnení znakov spôsobujúcich vznik tejto zodpovednosti. Napríklad v porovnaní s disciplinárnymi opatreniami uloženými páchatel'om disciplinárnych alebo služobných previnení (t. j. disciplinárnych deliktov osôb v služobnom pomere alebo v obdobnom pomere), kedy je možné uložit' disciplinárne opatrenia s rôznym stupňom intenzity, a to $v$ závislosti od druhu a stupňa závažnosti disciplinárneho previnenia (napríklad písomné pokarhanie, zniženie služobného platu až o 15 $\%$, a to na dobu najviac troch mesiacov (pri policajtoch) až po dobu najviac šest' mesiacov (pri profesionálnych vojakoch), zniženie hodnosti o jeden stupeň na dobu jedného roka, zákaz činnosti či prepadnutie veci) môže služobný úrad aplikovat' v rámci sankcionovania štátneho zamestnanca len ustanovenia zákona o štátnej službe o výpovedi zo strany služobného úradu alebo o okamžitom skončení štátnozamestnaneckého pomeru. Tieto „hraničné“ možnosti nepovažujeme za postačujúce a v rámci úvah de lege ferenda by bolo možné uvažovat' o zakomponovaní menej prísnejších d’alších sankcií za menej závažné porušenia služobnej disciplíny, inšpirujúc sa právnou úpravou disciplinárnych deliktov osôb v služobnom pomere alebo $v$ obdobnom pomere.

Koncepcia právnej zodpovednosti pritom nie je jedinou formou zodpovednosti, ktorá sa uplatňuje $v$ našej spoločnosti. Možno rozoznat' viacero vrstiev foriem zodpovednosti, a teda nielen tej právnej. Vidiet', že zodpovednost' ako fenomén sa prejavuje nielen v právnej, ale aj v mimoprávnej sfére (politická a morálna, prípadne sa zdôrazňuje, že má rozmer etický, 
filozofický, sociologický a aj ekonomický). Z hladiska právnej teórie bude, samozrejme, mat' význam sledovanie koncepcie zodpovednosti z právneho hladiska. Treba dodat', že ani pritom by sme nemali zabúdat' na širšie súvislosti zodpovednosti, a to predovšetkým z hladiska morálky a etiky (Horvat, 2017, s. 11). Na tento aspekt je potrebné prihliadat' aj pri porušovaní služobnej disciplíny a apelovat' na tieto mimoprávne normatívne systémy ako podporné pravidlá správania sa aj v príslušnej organizačnej štruktúre štátnej správy.

\section{Literatúra}

ČERVENÝ, Z. 1990. Podstata disciplinární odpovědnosti. In: Správní právo, no. 1. Praha.

Dohovor o ochrane ludských práv a základných slobôd.

Dôvodová správa k zákonu č. 55/2017 Z. z. o štátnej službe.

HORVAT, M. 2017. Administratívnoprávna zodpovednost' právnických osôb. Bratislava: vyd. Wolters Kluwer SK.

PRÁŠKOVÁ, H. 2016. Správní trestání. In: Hendrych, D. a kol. Správni právo - Obecná část. 6. vydání. Praha: C. H. Beck.

KOŠIČIAROVÁ, S. 2017. Správne právo hmotné. Všeobecná čast'. 2. vyd. Plzeň: Aleš Čeněk.

KOŠIČIAROVÁ, S. 2019. Ústavnoprávne aspekty $v$ uplatňovaní represívnej funkcie verejnej správy a disciplinárna zodpovednost' členov samosprávnych stavovských organizácii. In: Verejná správa $v$ súčasnom demokratickom a právnom štáte. Čast' 1 . Recenzovaný zborník príspevkov z medzinárodnej vedeckej konferencie. Košice: UPJŠ v Košiciach.

KRIŽAN, V.; ŽOFČINOVÁ, V. 2013. Pracovné právo pre neprávnikov. PIzeň: Aleš Čeněk.

KURIL, J. 2016. Disciplinárna zodpovednost' ako charakteristická črta verejnoprávnej povahy štátnozamestnaneckých vzt’ahov. In: Rusko, M; Kollár, V. (eds.) Sustainability - Environment - Safety '2016. Zborník z medzinárodnej vedeckej konferencie. Bratislava, 2016. Dostupné na internete: http://www.sszp.eu/wp-content/uploads/2016_conference_SES_p-37_Kuril_disciplin\%C3\%A1rna_zodpovednos\%C5\%A5_f41.pdf

KURIL, M. a kol. 2009. Základy pracovného práva. Bratislava: VŠEMVS.

MACHAJOVÁ, J. a kol. 2009. Všeobecné správne právo - 3. aktualizované vydanie. Bratislava: Poradca podnikatela.

MACHAJOVÁ, J. a kol. 2007. Všeobecné správne právo. Turany: Poradca podnikatela.

MATES, P. a kol. 2000. Základy správního práva trestního. Praha: C. H. Beck.

MATES, P.; MAZANEC, M. 1997. Disciplinární správní delikty. In: Právník, č. 7. Praha.

MOLITORIS, P. 2016. Konsenzuálne prostriedky alternatívneho riešenia sporov $v$ správnom konani. Košice: UPJŠ v Košiciach. 
Průcha, P. 2003. Správni právo - Obecná část. Brno: Masarykova univerzita.

SVÁK, J. 2011. Ochrana l'udských práv v troch zväzkoch - II. zväzok. Bratislava: Eurokódex.

ŠKULTÉTY, P. a kol. 2002. Správne právo hmotné - Všeobecná a osobitná čast'. Šamorín: Heuréka.

ŠKULTÉTY, P. a kol. 2004. Správne právo hmotné - Všeobecná čast'. Bratislava: VO PRAF UK.

VRABKO, M. a kol. 2018. Správne právo hmotné. Všeobecná čast'. 2. vydanie. Bratislava: C. H. Beck.

Zákon č. 372/1990 Zb. o priestupkoch v znení neskorších predpisov.

Zákon č. 55/2017 Z. z. o štátnej službe v znení neskorších predpisov.

\section{Adresa autorov}

JUDr. Róbert Gyuri, PhD.

Univerzita Pavla Jozefa Šafárika v Košiciach

Fakulta verejnej správy

Popradská 66

04132 Košice 1

E-mail: robert.gyuri@upjs.sk

Doc. JUDr. Mgr. Michal Jesenko, PhD.

Univerzita Pavla Jozefa Šafárika v Košiciach

Fakulta verejnej správy

Popradská 66

04132 Košice 1

E-mail: michal.jesenko@upjs.sk 